\title{
Folliculo-stellate Cells: Paracrine Communicators in the Anterior Pituitary
}

\author{
John Morris* and Helen Christian*
}

Department of Physiology, Anatomy \& Genetics, University of Oxford, South Parks Road, Oxford OX1 3QX, UK

\begin{abstract}
Most research on the anterior pituitary (adenohypophysis) has concentrated on the endocrine cells characterized by their complement of cytoplasmic dense-cored vesicles containing the classic anterior pituitary hormones. However it has become increasingly clear over the last 20 years that cells first identified more than 50 years ago in the basis that they lack such dense-cored vesicles and now known generically as folliculo-stellate or follicular cells have important physiological functions and act as an adenohypophysis wide communication system. This brief review reveals the need for this communication system, what we know of the plethora of products secreted by Folliculo-Stellate cells, the many receptors to which they respond, and in particular, the role of these enigmatic cells in the physiology of the stress/immune axis, the gonadotroph cells and the pituitary vasculature. Finally we review the current evidence that cells in this category can act as stem cells in the adult pituitary.
\end{abstract}

Keywords: Annexin 1, ABC-transporter, folliculo-stellate.

\section{THE NEED FOR COMMUNICATION IN THE ANTERIOR PITUITARY}

The need for local communication in the nervous system has always been accepted, but has often been overlooked in the anterior pituitary gland [1]. Rather, since the discovery of control of the pituitary from the hypothalamus and from feedback by peripheral hormones, there has been the implicit assumption that these two are sufficient to control the multiple scattered cells that comprise at least five major types of classic endocrine cells. However, this assumption ignores the need for communication between the different hormonal systems in the gland. Carl Denef and his group have pioneered the study of communication between many of the cells types and this work has already been well reviewed [2]. This review will concentrate on recent findings on the role of the 'non-endocrine' F-S (F-S) cells in providing a communication system throughout the anterior pituitary, and in particular its roles in the hypothalamopituitary-adrenal (HPA) stress axis including links with the immune system, the hypothalamo-pituitary gonadal axis, and the pituitary vasculature.

F-S cells form a meshwork throughout the anterior pituitary, linked by gap junctions and are able to signal via calcium waves [1, 3]; they produce numerous bioactive molecules and express many different types of receptor, but the intracellular mechanism of action of the receptors and the precise functional role of the signalling molecules produced by F-S cells is still unclear in many cases.

\section{IDENTIFICATION OF F-S CELLS: SUBTYPES}

F-S cells were first clearly identified in early electron microscopic investigations of the anterior pituitary on the

\footnotetext{
*Address correspondence to these authors at the Department of Physiology, Anatomy \& Genetics, University of Oxford, South Parks Road, Oxford OX1 3QX, UK; Tel: (01865) 272164; Fax: (01865) 272164;

E-mail: john.morris@dpag.ox.ac.uk; helen.christian@dpag.ox.ac.uk
}

basis of morphological criteria [4]. They were named for their extensive star-like radiating processes and for the microvillus-lined follicles which are formed where the F-S cells come together. They form about $10 \%$ of the cell population of the adenohypophysis [5]. The introduction of immunocytochemistry added the presence of S-100 protein [6] and the absence of other classic anterior pituitary hormones as a second identification criterion which has been used extensively. Since then F-S cells and cell lines have been shown to produce many other markers (e.g. vimentin, annexin A1 (Anx A1), glutamine synthase) and bioactive molecules (see below). The finding that some F-S cells produce certain signalling molecules but apparently not others has led to an understanding that F-S cells are not a homogeneous group [7, 8]. However, apart from studies on laser-captured F-S cells which showed that these native F-S cells and the TtT/GF cell line (see below) expressed the mRNAs for glial fibrillary acidic protein (GFAP), S100 protein, transforming growth factor- $\beta 1$ (TGF $\beta 1$ ), TGF $\beta$ receptor, interleukin-6, leptin, the leptin receptor, pituitary adenylate cyclase-activating polypeptide (PACAP), and PACAP receptors $[9,10]$, there have been relatively few studies on gene expression by native F-S cells or on the stimulatory or inhibitory action of their numerous receptors on the synthesis of their biomarkers. This coupled with the difficulty of showing by immunocytochemistry that a cell does not produce a biomarker, means that the understanding of the heterogeneity of F-S cell subtypes is in its infancy.

F-S cells are linked by gap junctions which, like gap junctions elsewhere, are dynamic structures allowing variable degrees of communication. The extent of this communication has been investigated in a large series of experiments by Soji and Herbert $[11,12]$ and is increased by a number of the signals that act on F-S cells (see below). There is also some evidence for a few gap junctions between F-S and endocrine cells [13]. 
Relatively little is know about the life history of F-S cells, including their origin. but their number appears to decrease during aging in both rats [14] and humans [15]. In contrast, the expression of glutamine synthase in rats increases markedly from the neonatal period to adulthood [16].

\section{MORPHOLOGY OF F-S CELLS AND THE FOLLI- CLES}

F-S cells are small cells which at first sight are of rather uninteresting appearance. The nucleus is ovoid with both hetero- and euchromatin, surrounded by relatively sparse cytoplasm containing mitochondria, some rough and smooth endoplasmic reticulum and generally few lysosomes. The feature that first identified the cells was their star-like shape and the lack of dense-cored secretory granules that characterise all the other 'endocrine' cells. The cytoplasmic processes that extend from the cell bodies are difficult to make out in immersion-fixed material in which the extracellular space appears minimal, but are much more obvious in perfusion-fixed tissues in which the extracellular space appears expanded (Fig. 1). Such fixation also highlights the numerous robust connections between the F-S cells and the classic endocrine cells, and in which both gap and adherent junctions have been reported. Where F-S cells come together, they are linked at a number of points by obvious junctional complexes with both adherent and gap junctions (Fig. 2) and, on the intervening space (but no other part of their surface), the membrane is expanded by numerous microvillus-like processes (Fig. 1). This appearance strongly suggests some transport role, but what this might be is currently unknown. When grown in primary culture, bovine F-S cells form monolayers; shortly after reaching confluence the monolayers develop 'domes', a feature characteristic of cells that function as polarized transport epithelia. These monolayers cells express a high level of $\mathrm{Na}^{+} / \mathrm{K}^{+}$-ATPase and display an apical amiloridesensitive $\mathrm{Na}^{+}$conductance, and basal $\mathrm{Na} / \mathrm{K}$-ATPase, allowing for transcellular $\mathrm{Na}^{+}$transport, which could contribute to ionic control in the pituitary [17]. The regulatory protein Anx A1 is localised around the follicles by pre-embedding immunocytochemistry [18]. At the cell surface Anx A1 is colocalized with the ATP-binding cassette transporter A1, which is involved in the export of Anx A1 (and could be involved with the export of other peptides such as S-100, VEGF, bFGF), at the ends of F-S cell processes, and Anx A1 immunoreactivity is concentrated at points of contact with endocrine cells [19] (Figs. 2, 3). Such contacts are therefore well placed to influence the endocrine cells. Other transporters shown to be present in FS cells, but which have not been precisely localized subcellularly, include the thyroid hormone transporter MCT8 [20] the proton-peptide cotransporter PepT2 [21] and the cystine-glutamate transporter that is associated in other glial cells with glutamate release [22]. The dipeptides carnosine and homocarnosine are taken up by F-S cells [23]. The physiological function of this is unclear, but uptake of such peptides can be used to trace the F-S cell communication system $[1,3]$.

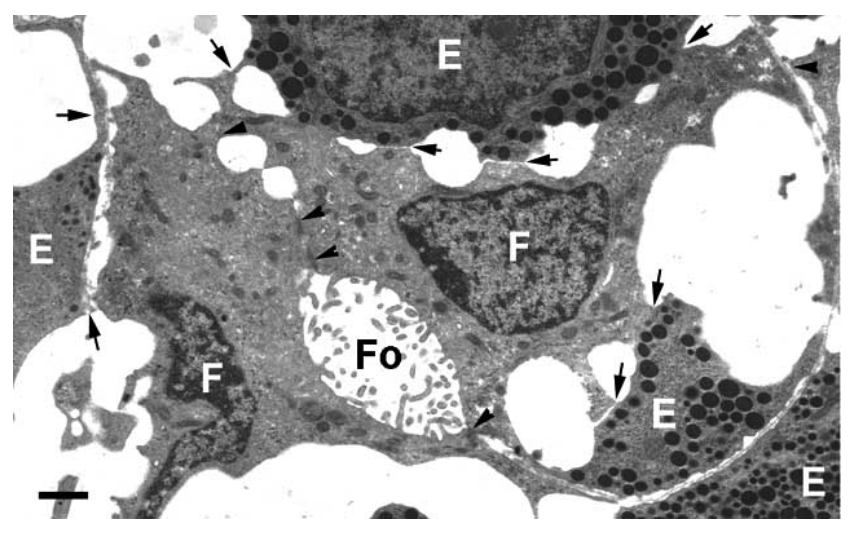

Fig. (1). Electron micrograph of mouse anterior pituitary to show the F-S (F) and classical endocrine (E) cells characterized, respectively, by the lack and the presence of dense-cored secretory vesicles, the expansion of the extracellular space that is seen in perfusion-fixed material, the microvilli decorating the membrane of the follicle (Fo) formed where F-S cells come together, and the numerous points of strong contact between the F-S cells (arrowheads) and between F-S and endocrine cells (arrows). Bar = $1 \mu \mathrm{m}$. (Modified from Fig. 4 [19]).

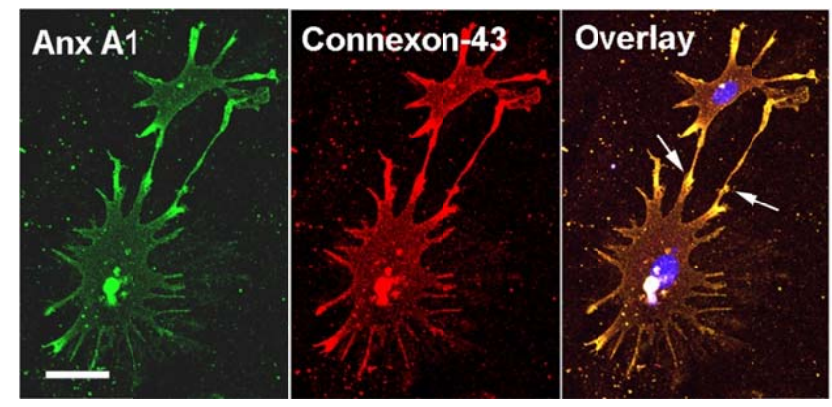

Fig. (2). Confocal fluorescence microscope images of F-S like $\mathrm{TPit} / \mathrm{F} 1$ cells to show annexin A1 immunoreactivity, connexon-43 immunoreactivity, and the overlay image showing colocalization. The cells have been very lightly fixed to emphasize the proteins localized at the surface of the tips of the processes of the cells. Connexon immunoreactivity is particularly prominent where the cell processes have come together (arrows). Bar $=5 \mu \mathrm{m}$.

Apart from the export of Anx A1 and other peptides, the role of transporters and particularly the follicles is unclear, though they could provide a novel intrapituitary means of circulation for paracrine signalling molecules and nutrient substrates required for hormone synthesis. F-S cells would be well placed to coordinate the pituitary response to changing physiological demands, e.g. during pregnancy, lactation, weaning and puberty, when the pituitary has the ability to expand and contract its activity and cell numbers several fold.

\section{F-S CELL LINES}

The isolation of F-S cells from intact pituitaries is not an easy task, so it is no surprise that the majority of recent experiments on F-S cells have used a number of cell lines. The F-S cell community is very indebted to Professor Kinji Inoue of Saitama University, Japan, who produced the two F-S cell lines that have been most widely used. TtT/GF cells 
$[24,25]$ were derived from a mouse pituitary tumour and have been used most extensively; Tpit/F1 cells [26], derived from a temperature-sensitive large $\mathrm{T}$ antigen transgenic mouse; both have very similar morphology to native F-S cells and very similar properties. While the availability of these cell lines has been most useful, there is often the implicit assumption that these cell lines entirely represent the native F-S cells. However, TtT/GF cells lack nNOS [27] and we have recently found that, unlike native rat cultured F-S cells [28], TtT/GF cells do not respond to acetylcholine by a rise in intracellular calcium $\left([\mathrm{Ca}]_{\mathrm{i}}\right)$ although they can respond to acetylcholine by exporting Anx A1 [29]. The first human F-S cell line (PDFS) was derived spontaneously from a clinically non-functioning pituitary macroadenoma [30]. A further human hPit-1 cell line was derived which lacked classical pituitary hormones but expressed high levels of follistatin mRNA suggesting an origin from F-S cells [31]. PDFS cells show similar morphology to primary F-S cells, and express vimentin, S-100, follistatin, activin A and the activin intracellular signalling pathway. The PDFS cells also export Anx A1 [32] and express toll-like receptor (Tlr4), the receptor which induces lipopolysaccharide signals [33]. More recently a rat F-S cell line, FS/D1h cells, [34] has also been established. As with all cell lines [35], caution needs to be observed because there may well be species differences in F-S cell signals, receptors and intracellular mechanisms that are currently overlooked. More information about what is expressed by the native FS cells and how that expression is controlled, is urgently required.

\section{PARACRINE SIGNALS PRODUCED BY F-S CELLS}

F-S cells produce a large number of different signalling molecules; those not primarily associated with the immune system (see below) are summarised in Table 1. Their actions are briefly summarised here. Anx A1 is a glucocorticoidinduced and exported molecule which mediates the earlydelayed (30min-3h) inhibitory effects of glucocorticoid action on most pituitary endocrine cells (see below). Follistatin is produced both by F-S cells (Fig. 3) and gonadotrophs. It acts on gonadotrophs to bind activin and thereby inhibit FSH secretion. Follistatin secretion in the pituitary is markedly increased by gonadotrophin releasing hormone $(\mathrm{GnRH})$ at the time of the preovulatory surge [36] but the cellular source is unclear because there is no evidence that F-S cells express GnRH receptors. Activin, which likewise is also produced by gonadotrophs, has been reported only in the human PDFS cell line, but if expressed by F-S cells in primary tissue would act on gonadotrophs to stimulate FSH secretion and to decrease growth hormone (GH) and adrenocorticotrophic hormone (ACTH) secretion [30]. Basic fibroblast growth factor has been reported only in $\mathrm{GH}$ cells in the human pituitary [37] but is present in ratderived F-S cells where it is responsible for determining the sensitivity of lactotrophs to the mitogenic effects of estradiol [38] and is stimulated by TGF- $\beta 3$ [39]. Pituitary vascular endothelial growth factor (VEGF) was first described in bovine F-S cell-conditioned medium [40] and presumably controls pituitary vascularity in both physiological and pathological conditions such as tumour formation.

Leptin production appears to vary considerably among species. It is prominent in F-S cells in humans, but sparse in rat pituitary and in $<1 \%$ of mouse pituitary cells though it is expressed by many cells in the murine TtT/GF cell line. Its local function seems to be to suppress proliferation of somatotrophs and F-S cells (which also express leptin receptors [41, 42]. Ciliary neurotrophic factor similarly suppressed proliferation, but also enhances gap-junction formation between F-S cells in castrated male rats [43].

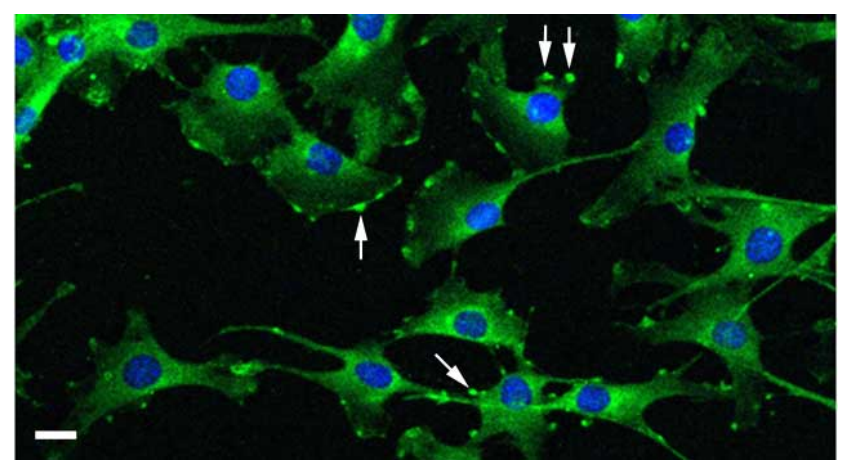

Fig. (3). Follistatin immunoreactivity revealed by confocal fluorescence microscopy of F-S like TtT/GF cells. The cells have been fixed a little more strongly than those in Fig. (2) so that the even distribution of immunoreactivity in the cytoplasm is apparent, together with the points of intense surface immunoreactivity at the tips of processes of the cells (arrows). Bar $=5 \mu \mathrm{m}$.

There is relatively little information about the control of expression of some of these signalling molecules. Anx A1 synthesis is stimulated by glucocorticoids $[18,59]$ and also by oestradiol, causing Anx A1 expression appropriately through the oestrous cycle [60] in rats. Follistatin expression and export from F-S cells is stimulated by interleukin-1 $\beta$ and also by glucocorticoids and lipopolysaccharide [47].

Expression of bFGF, like that of Anx A1, is stimulated by estradiol [50]; it is also stimulated by transforming growth factor beta (TGF $\beta$ ) by a mechanism that involves protein kinase $\mathrm{C}(\mathrm{PKC})$ and mitogen-activated protein kinase (MAPK) [61]. Basic FGF can stimulate the proliferation of $\mathrm{TtT} / \mathrm{GF}$ cells by an autofeedback mechanism that involves Src tyrosine kinase and protein kinase C [62].

VEGF expression is also stimulated by TGF $\beta$ [63] and by many other factors including: low oxygen tension via hypoxia-inducible factor 1 (HIF-1); IL-6; PACAP; (VIP); estradiol; but is inhibited by glucocorticoids [51]. All of these could act in the pituitary and we have demonstrated the stimulatory effects of PACAP and estradiol and the inhibitory effect of glucocorticoids on TtT/GF cells [55]. Gonadotrophins have been shown to induce VEGF secretion in the ovary, and thyroid stimulating hormone in thyroid carcinoma cell lines, but whether either of these act in the pituitary is unknown.

Nitric oxide production by F-S cells is stimulated by interferon $\gamma$ [57], leptin [64] and adenosine triphosphate (ATP) [26] and has inhibitory effects on the secretion of prolactin (PRL) but not luteinizing hormone (LH) [65]. Interestingly, nNOS appears to be expressed mainly in F-S cells in male rats but in gonadotrophs in females; 
Table 1. Signalling Molecules Produced by F-S Cells and F-S Cell-Like Cell Lines

\begin{tabular}{|c|c|c|}
\hline Signalling Molecule & Identified Source & Reference \\
\hline \multirow{4}{*}{$\begin{array}{l}\text { Annexin A1 (Anx A1; } \\
\text { Anx A1; lipocortin 1) }\end{array}$} & Rat pituitary & {$[44]$} \\
\hline & $\mathrm{TtT} / \mathrm{GF}$ cells & {$[44]$} \\
\hline & Tpit/F1 cells & See Fig. 2 \\
\hline & PDFS cells & {$[30,45]$} \\
\hline Follistatin & Rat pituitary F-S cells & {$[46,47]$} \\
\hline Activin & Human PDFS cells & {$[30]$} \\
\hline \multirow{3}{*}{$\begin{array}{l}\text { Basic fibroblast growth } \\
\text { factor (bFGF) }\end{array}$} & Bovine F-S cells & [48] \\
\hline & Rat pituitary F-S cell line & [49] \\
\hline & Rat F-S cells & {$[27]$} \\
\hline \multirow[t]{4}{*}{$\begin{array}{l}\text { Vascular endothelial } \\
\text { growth factor (VEGF) }\end{array}$} & $\begin{array}{l}\text { Bovine F-S conditioned } \\
\text { medium }\end{array}$ & {$[48,51]$} \\
\hline & Rat pituitary F-S cells & {$[52]$} \\
\hline & Human pituitary F-S cells & [53] \\
\hline & $\mathrm{TtT} / \mathrm{GF}$ cells & {$[24,54,55]$} \\
\hline \multirow{3}{*}{$\begin{array}{l}\text { Nitric oxide (NO) from } \\
\text { neuronal NOS }\end{array}$} & Rat pituitary F-S cells & {$[56]$} \\
\hline & $\mathrm{TtT} / \mathrm{GF}$ cells & [57] \\
\hline & Tpit/F1 cells & {$[26]$} \\
\hline $\begin{array}{l}\text { Novel neurotrophin-1/B- } \\
\text { cell stimulating factor-3 } \\
\text { (NNT-1BSF-3) }\end{array}$ & $\mathrm{TtT} / \mathrm{GF}$ & {$[58]$} \\
\hline \multirow{2}{*}{$\begin{array}{l}\text { Pituitary adenylate } \\
\text { cyclase-activating peptide } \\
\text { (PACAP) }\end{array}$} & Rat pituitary F-S cells & {$[42]$} \\
\hline & $\mathrm{TtT} / \mathrm{GF}$ cells & {$[42]$} \\
\hline \multirow{2}{*}{$\begin{array}{l}\text { Transforming growth } \\
\text { factor } \beta 1 \text { (TGF } \beta 1)\end{array}$} & Rat pituitary F-S cells & {$[42]$} \\
\hline & $\mathrm{TtT} / \mathrm{GF}$ cells & [42] \\
\hline \multirow[t]{3}{*}{ Leptin } & Rat pituitary F-S cells & [42] \\
\hline & Human pituitary F-S cells & {$[40]$} \\
\hline & $\mathrm{TtT} / \mathrm{GF}$ cells & {$[42]$} \\
\hline
\end{tabular}

gonadectomy of males decreases nNOS in FS cells but increases it in gonadotrophs [66].

\section{MECHANISMS OF EXTERNALISATION OF F-S SIGNALLING MOLECULES}

A defining characteristic of F-S cells is their lack of dense-cored secretory vesicles. Whereas nitric oxide can simply diffuse from the cells, the proteins and peptides must either be secreted via the constitutive route, or be transported across the membrane. Anx A1, follistatin (Fig. 4) and VEGF are all distributed diffusely in the cytoplasm of native and cultured F-S cells. The export of Anx A1 from F-S cell lines has been more extensively studied. Solito et al. [30] have shown in PDFS cells that dexamethasone, which causes rapid membrane association and export of Anx A1, induces rapid serine-phosphorylation of Anx A1 and involves a nongenomic action of the glucocorticoid receptor, protein kinase $\mathrm{C}$, phosphatidylinositol 3-kinase, and mitogen-activated protein kinase. Glucocorticoids cause the export of Anx A1 which is evident after 30 mins and maximal at 90 mins. The ATP-binding cassette (ABC) transporter family is known to export a number of proteins, including bFGF [67] and Anx A1 in inflamed gut mucosa [69]. Glyburide, an ABC transporter inhibitor, markedly inhibits glucocorticoidstimulated (but not potassium-stimulated) export of Anx A1from TtT/GF cells and from pituitary tissue [69]. ABC transporter protein is co-localized with Anx A1 at the tips of processes of TtT/GF cells (Fig. 4); both are increased by glucocorticoid exposure, and export of Anx A1 has been shown by immuno-electron microscopy of intact pituitary to occur where F-S cell processes abut adjacent endocrine cells [19] (Fig. 5). Evidence for a role of ABC-A1 was strengthened by the finding that the ABC-A1 inhibitors geranyl-geranyl pyrophosphate and sulfobromophthalein both significantly inhibit Anx A1 export and that partial silencing of $\mathrm{ABC}-\mathrm{A} 1$ expression by siRNA significantly decreased the amount of cell surface Anx A1. By contrast, ABC-A1-null mice appear to externalize Anx A1 normally, though compensation by other $\mathrm{ABC}$ transporters may have occurred. However, co-transfection of ABC-A1 and Anx A1 into Xenopus oocytes and of ABC-A1-GFP and Anx A1 into AtT20 corticotrophs both strongly suggest that ABC-A1 plays at least a major role in Anx A1 export [70].

The timescale of VEGF secretion (just detectable at $3 \mathrm{~h}$, well established at 24h) is reminiscent of constitutive secretion via small electron-lucent vesicles. The sulphonylurea glyburide (glibenclamide) is perhaps better known as an antidiabetic agent, acting by inhibiting ATPsensitive potassium channels in pancreatic beta cells, thereby depolarising the cells, allowing voltage-sensitive calcium channels to open, increasing intracellular calcium and thereby stimulating insulin release. Our experiments [55] have shown that $\mathrm{TtT} / \mathrm{GF}$ cells express $\mathrm{K}_{\mathrm{ATP}}$ channels (Kir 6.1 and SUR2B). When VEGF secretion from the TtT/GF cells was tested, glyburide $(100 \mathrm{nM})$ on its own produced as great or greater stimulus of $24 \mathrm{~h}$ VEGF secretion as did the wellknown secretagogue PACAP $(100 \mathrm{nM})$, but also markedly facilitated the effect of PACAP when co-applied. By contrast diazoxide, which opens the $\mathrm{K}_{\mathrm{ATP}}$ channels, inhibited both glyburide- and PACAP-induced secretion of VEGF. Enhancement of $[\mathrm{Ca}]_{\mathrm{i}}$ therefore appears to be important for stimulation of VEGF secretion. How this links with the known requirement of PKC for Anx A1 phosphorylation and export is currently unknown. Although follistatin secretion in response to interleukin $1 \beta$ has been measured, the $48 \mathrm{~h}$ stimulation period tested [47] provides no clue to the mechanism involved.

\section{INPUTS TO F-S CELLS: RECEPTORS AND MECHA- NISMS OF ACTION}

In order to act as the hubs of a signalling system, F-S cells must express a number of receptors. Those involved with interaction with the immune system are listed in Table 3; other known receptors are listed in Table 2. "Implied" indicates that the evidence for the receptor rests on a defined action, and not on actual identification of the receptor on the cells. 


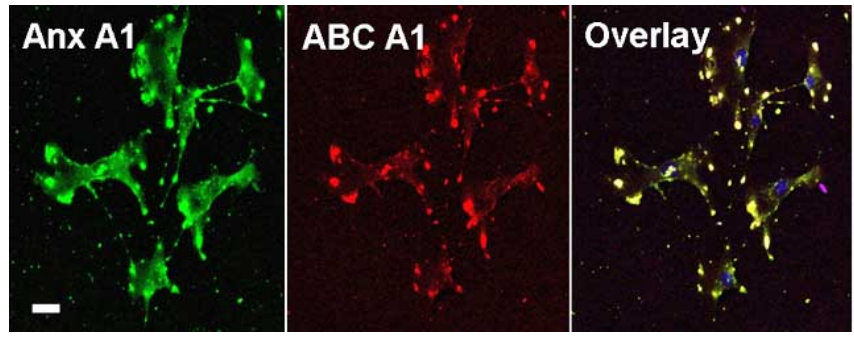

Fig. (4). Confocal fluorescence microscope images of F-S like TtT/GF cells to show annexin (Anx A1) immunoreactivity, (b) ABC-A1 transporter immunoreactivity, and (c) the overlay image showing colocalization. Annexin is evenly distributed through the cytoplasm and is co-localized with $\mathrm{ABC}-\mathrm{A} 1$ at the tips of processes. Bar $=5 \mu \mathrm{m}$.

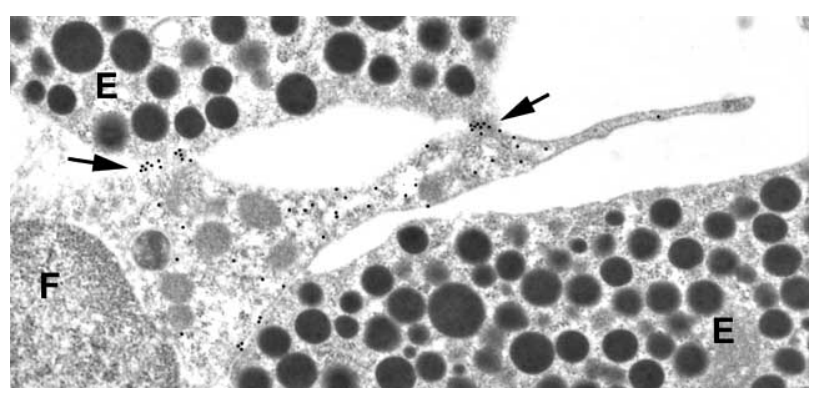

Fig. (5). Electron micrograph of mouse pituitary immunogoldlabelled for annexin A1. Immunoreactivity is seen throughout the cytoplasm of the F-S cell (F) and concentrated at points on the surface of the F-S cells where they make contact with the membrane of surrounding endocrine cells $(\mathrm{E})$. Bar $=1 \mu \mathrm{m}$.

One immediately striking feature of Table $\mathbf{2}$ is that there is no direct evidence that F-S cells express receptors for any of the hypothalamic releasing/inhibiting peptides with the exception of PACAP, or for any of the classic anterior pituitary hormones with the possible exception of the thyrotrophin receptor in human pituitaries [80]. The hypothalamic cells expressing PACAP are found largely in the paraventricular (parvo- and magnocellular divisions), supraoptic and arcuate nuclei. Their axons project to the median eminence and the concentration of PACAP in portal blood is higher than that in the systemic circulation. Not only the F-S cells, but all the endocrine cells are influenced by PACAP primarily via the PAC1 receptor which induces rises in cytosolic calcium [81]. Thus PACAP can have effects both to stimulate release of ACTH, GH, and PRL (but not TSH), but also, via F-S cell Anx A1 to inhibit it; to stimulate FSH synthesis directly or to inhibit it via F-S cell follistatin; it also stimulates IL-6 secretion and VEGF secretion, thereby having indirect effects on differentiation of pituitary cells and pituitary vasculature ([82].

Estradiol, acting through nuclear ER stimulates F-S cell production of VEGF [83]. It also acts via a PKC-dependent MAP-K p44/42 pathway, interacting with TGF-beta 3 to increase bFGS and thereby cause proliferation of lactotrophs [38]. Estradiol can also block the stimulatory effect of glucocorticoids on $11 \beta$-hydroxysteroid dehydrogenase expression (Shun-Shin and Morris, unpublished observations) which could explain in part the desensitisation of the stress response in pregnant female rats [84]. Little is known of the action of androgens on F-S cells; they suppress follistatin production in vivo, but not in a F-S cell line [85].

F-S cells contain classic intracellular glucocorticoid receptors which migrate from the cytoplasm to the nucleus on binding. Glucocorticoids exert transcriptional actions to increase the synthesis of Anx A1 and follistatin and to decrease the synthesis of VEGF. They also induce the much faster non-genomic intracellular events that are blocked by cycloheximide but not actinomycin D [86] and which lead to the phosphorylation of serine-27 that is essential for externalisation of Anx A1 from F-S cells and cell lines within 30 minutes. These include activation of protein kinase $\mathrm{C}$, phosphatidylinositol 3-kinase, and mitogen-activated protein kinase and also required HMG-coenzyme $\mathrm{A}$ and myristoylation [87]. However, the exact route(s) by which these components are involved remains to be determined.

Leptin probably acts on the F-S cell long and short leptin receptors to activate STAT 3 and other pathways to inhibit F-S cell proliferation, but the mechanism has not been experimentally tested.

The adenosine receptors on F-S cells signal via Gq/PLC $\left(A_{1} R, A_{2 B} R\right)$ and $G s /$ adenyl cyclase $\left(A_{2 B} R\right)$, the stimulation of $\mathrm{A}_{2 \mathrm{~B}}$ receptors causing proliferation of TtT/GF cells and increasing VEGF and IL-6 production [88, 89] and thrombomodulin expression and gap junction proteins [78]. The source of adenosine is unclear; it is derived from the diet, but may be generated locally because ecto-5'nucleotidase is expressed by $\sim 20 \%$ of pituitary cells, in particular lactotrophs and somatotrophs, and coculture of $\mathrm{TtT} / \mathrm{GF}$ cells with somatomammotrophs increases the expression of connexon 43 [88].

The purinergic receptors $\mathrm{P} 2 \mathrm{Y}$ and $\mathrm{P} 2 \mathrm{X}$ are widely expressed in the pituitary. Adenosine triphosphate (ATP) acts on rat primary F-S cells via P2Y receptors, phospholipase $\mathrm{C}$ and IP3 to release calcium from intracellular stores. It causes a dose-dependent release of Anx A1 from TtT/GF cells. Acetylcholine acts on cultured primary rat F-S cells via muscarinic receptors to stimulate calcium transients by causing release from intracellular stores [28]. However, our TtT/GF cell cultures fail to generate calcium transients to even larger doses of acetylcholine, although they readily respond in this way to ATP (Morris, Williams, Christian, unpublished observations).

ATP is co-released with classical anterior pituitary hormones when the dense-cored vesicles are exocytosed. Given the proximity of F-S cell processes and the ability of ATP to stimulate Anx A1 release, this suggests an ultrashort negative feedback loop whereby an endocrine cell that has been particularly active will stimulate surrounding F-S cells to secrete Anx A1 and thereby damp down its secretory activity.

Choline is generally thought to act through nicotinic $\alpha 7$ receptors [90], but there is no evidence that these occur in pituitary F-S cells, or that choline causes an increase in intracellular calcium. Despite this, choline causes a dosedependent increase in Anx A1 export from TtT/GF cells [29]. This implies the existence of another possible mechanism of choline action in these cells. 
Table 2. Receptors Expressed by F-S Cells but not Primarily Associated with Immune or Inflammatory Mechanisms System

\begin{tabular}{|c|c|c|}
\hline Receptor/known response & Tissue & Reference \\
\hline PACAP (PACI > PACII) & Rat pituitary F-S cells & {$[71,72]$} \\
\hline Estradiol (ER $\alpha, E R \beta)$ & $\mathrm{TtT} / \mathrm{GF}$ cells & {$[60]$} \\
\hline Androgen & $\mathrm{TtT} / \mathrm{GF}$ cells & $\begin{array}{c}\text { Morris \& } \\
\text { Christian, } \\
\text { unpublished }\end{array}$ \\
\hline \multirow{2}{*}{$\begin{array}{l}\text { Glucocorticoid (classic \& } \\
\text { non-genomic actions) }\end{array}$} & Rat pituitary & {$[73]$} \\
\hline & $\mathrm{TtT} / \mathrm{GF}$ cells & [19] \\
\hline \multirow{4}{*}{$\begin{array}{l}\text { Leptin (common, ObRa and } \\
\text { long, ObRb forms) }\end{array}$} & Mouse pituitary & {$[42]$} \\
\hline & Rat pituitary & {$[42]$} \\
\hline & $\mathrm{TtT} / \mathrm{GF}$ cells & {$[42]$} \\
\hline & Human pituitary & {$[41]$} \\
\hline $\begin{array}{l}\text { Vascular endothelial growth } \\
\text { factor (VEGF; Flk-1) }\end{array}$ & Rat pituitary & [74] \\
\hline $\begin{array}{l}\text { Ciliary trophic nerve factor } \\
\text { (CNTF) }\end{array}$ & $\mathrm{TtT} / \mathrm{GF}$ cells & [75] \\
\hline \multirow{2}{*}{$\begin{array}{l}\text { Transforming growth factor } \beta \\
\text { (TGF } \beta \text { ) implied }\end{array}$} & Rat F-S cell line & {$[42,76]$} \\
\hline & $\mathrm{TtT} / \mathrm{GF}$ cells & {$[42]$} \\
\hline \multirow{2}{*}{$\begin{array}{l}\text { Platelet-derived growth factor } \\
\qquad \text { (PDGF) }\end{array}$} & Rat pituitary & {$[77]$} \\
\hline & $\mathrm{TtT} / \mathrm{GF}$ cells & \\
\hline Adenosine $A_{1} R, A_{2 B} R$ & TtT/GF. Tpit/F1 cells & [78] \\
\hline \multirow[t]{2}{*}{$\begin{array}{l}\text { Adenosine trisphosphate } \\
\text { (ATP; P2Y, P2X) }\end{array}$} & Rat pituitary F-S cells & [79] \\
\hline & $\mathrm{TtT} / \mathrm{GF}$ cells & $\begin{array}{l}\text { Williams, } \\
\text { Morris, } \\
\text { Christian, } \\
\text { unpublished }\end{array}$ \\
\hline $\begin{array}{l}\text { Acetylcholine, muscarinic } \\
\text { (implied) }\end{array}$ & Rat pituitary F-S cells & {$[28]$} \\
\hline Choline (implied) & $\mathrm{TtT} / \mathrm{GF}$ cells & [29] \\
\hline Bradykinin (implied) & Rat pituitary F-S cells & {$[72]$} \\
\hline $\begin{array}{l}\text { Angiotensin-II (AT-1; } \\
\text { implied) }\end{array}$ & Rat pituitary F-S cells & {$[72]$} \\
\hline Endothelin-1 (implied) & Rat pituitary F-S cells & {$[72]$} \\
\hline
\end{tabular}

TGF $\beta$ from lactotrophs increases gap-junction communication among F-S cells and stimulates the release of bFGF which acts back on lactotrophs. In this way the stimulation of lactotrophs by estradiol can lead to lactotroph tumours via F-S cell bFGF [76].

F-S cells express a PDGF receptor which acts via PI3 kinase and Akt to increase F-S cell proliferation and VEGF secretion [77].

\section{COMMUNICATION WITH THE HYPOTHALAMO- PITUITARY ADRENAL STRESS AXIS}

One of the prime ways in which F-S cells communicate with the endocrine cells in the anterior pituitary is via the action of glucocorticoids feeding back negatively in the stress response. There is at present no evidence that either corticotrophin-releasing hormone or vasopressin (both stimulants of ACTH release) act on F-S cells. It is not often appreciated that glucocorticoid negative feedback occurs in three different but overlapping time frames and by three different mechanisms, although much attention is paid to pulses and circadian rhythms of ACTH secretion. There is a rapid feedback which occurs within 30 minutes. This inhibits release of ACTH by a mechanism which involves a nongenomic change in membrane potential and inhibition of $\mathrm{CRH}$-induced cAMP production [91]. After several hours, the well understood GR-induced inhibition of POMC transcription and processing to ACTH occurs. Between these two (30 minutes to 3 hours) is the 'early-delayed' feedback period and it is here that F-S cell Anx A1 is essential. Exposure of F-S cells to glucocorticoids not only increases the synthesis of Anx A1 but also causes its externalisation from the cells (see above). This occurs at particular foci in the cell membrane in both native F-S and TtT/GF cells where the Anx A1 is co-localized with the ABC-A1 transporter (Fig. 4) and also with cytoskeletal elements, S100 and connexin 43 (Fig. 2).

Stress levels of glucocorticoids inhibit the secretion of all pituitary endocrine cells, not only the corticotrophs. Most of the endocrine cells contain glucocorticoid receptors and so are subject to transcriptional inhibition by glucocorticoids, but lactotrophs apparently do not [73] and all are subject to the early delayed glucocorticoid-induced inhibition that requires Anx A1 as demonstrated by the blocking effects of both antibodies and antisense [92, 93]. F-S cells make functional contacts with all the classical endocrine cell types in proportion to their number and the Anx A1 that they export can therefore exert the early-delayed feedback on secretion of all adenohypophyseal hormones. Immunoelectron microscopy (Fig. 5) shows Anx A1 immunoreactivity concentrated at some of these points of contact between F-S and endocrine cells [19] so that F-S cells appear to be able to deliver Anx A1 very precisely to endocrine cells through what could be considered a sort of 'endocrine synapse'. The extent to which this is controlled is completely unknown but will be interesting to investigate. Certainly, co-culture experiments involving TtT/GF cells and AtT20 corticotrophs show that glucocorticoid inhibition of CRH-induced ACTH secretion is proportional to the number of $\mathrm{TtT} / \mathrm{GF}$ cells present [94].

Glucocorticoids can also influence the HPA axis through interleukin-6 (IL-6; see section on Communication with immune system) produced by F-S cells. IL-6 is a strong stimulant of the HPA axis and its expression is stimulated by TGF $\beta$, PACAP and glucocorticoids $[95,96]$. At present it is 
not known how the apparently conflicting effects of glucocorticoid-induced secretion of Anx A1 and IL-6 are physiologically controlled. Perinatal glucocorticoid treatment of rats increases IL- 6 production, but decreases Anx A1 production and the size of F-S cells [97]. This suggests that F-S cells are implicated in the known influence of perinatal stressful events in the heightened sensitivity of the HPA stress axis in adults.

One other way in which F-S cells can influence the stress axis is during development via an effect on the number of corticotrophs. Lack of Anx A1 in Anx A1-null mice is associated with a 4-fold increase in the number of corticotrophs in the male but not the female null mice [98] and the same is seen in Anx-receptor null animals. However, the individual corticotrophs in the male null mice were smaller and had fewer dense-cored secretory vesicles. In null males pituitary ACTH and IL-6 were increased, but plasma corticosterone and ACTH were unchanged.

F-S cells therefore play a variety of different roles in the stress axis. They determine the number of corticotrophs, mediate an important component of glucocorticoid negative feedback on ACTH during stress, but also play a role in the stress-induced inhibition of all the other pituitary hormones.

\section{COMMUNICATION WITH THE HYPOTHALAMO- PITUITARY GONADAL AXIS}

F-S cell communication with the reproductive axis occurs largely via the effects of follistatin on gonadotrophs, though the action of Anx A1 to inhibit gonadotrophs [99] and lactotrophs and of bFGF to mediate oestrogen-induced lactotroph proliferation will have indirect effects on the gonadotrophs [2]. Follistatin in F-S cells is increased by glucocorticoids, IL-1 $\beta$ and by this mechanism stresses of many types can inhibit FSH production and also sensitivity to gonadotrophin-releasing hormone $(\mathrm{GnRH})$ by inhibition of GnRH receptor expression [100]. PACAP also stimulates follistatin expression in FS cells [101] but this is difficult to interpret until the controls on PACAP secretion are better understood. A human F-S cell line is also said to produce activin, but the controls on this are not known [30]. A further complication in assessing the role of F-S cell signals is that the gonadotroph cells themselves produce both activin and follistatin $[102,103]$.

\section{COMMUNICATION WITH THE IMMUNE SYSTEM}

F-S cells display many characteristics of immune cells and there is good evidence that they mediate and modulate the neuroendocrine response to immune stress and inflammation [104]. F-S cells respond to bacterial endotoxins by producing cytokines that in turn influence hormonal output from the anterior lobe 'classical' secretory cells [2]. The expression of many immune cell markers and the release of cytokines by F-S cells (summarised in Table 3) together with ultrastructural similarities led to speculation that FS cells might represent either pituitary specific macrophage or dendritic-like cells [105]. Dendritic cells and macrophages are two groups of non-lymphoid mononuclear cells involved in immune responses through the production of a variety of cytokines, presentation of antigens to lymphocytes and phagocytosis/degradation of unwanted material [106]. Whereas FS cells undoubtedly show some characteristics of macrophages, a number of reports have been unable to detect cells in rat or human pituitary that colocalise the F-S marker S100 with well known macrophage markers such as OX42, ED1 or CD45 [107109]. However, Allaerts et al. [7, 107] demonstrated coimmunolabeling for S100 and the dendritic specific marker OX6 in a subpopulation (10-20\%) of F-S cells in the rat pituitary. These findings raised the possibility of a myeloid origin of a proportion of F-S cells (reviewed in [110]). It is possible that only this subset of $\mathrm{S}_{100}{ }^{+\mathrm{ve}} \mathrm{OX} 6^{+\mathrm{ve}} \mathrm{F}-\mathrm{S}$ cells supports the intrapituitary response to immune stimuli. Therefore, because many studies investigating immune properties of F-S cells have relied on TtT/GF cells it may be that the TtT/GF cell line was established from this particular subpopulation of FS cells. However to our knowledge the expression of OX6 or other dendritic markers has not been investigated in $\mathrm{TtT} / \mathrm{GF}$ cells. Ultrastructural studies in rat and guinea fowl have suggested a phagocytic role for F-S cells [111-113]. We are not aware of functional studies to support this and have been unable to demonstrate phagocytic activity by native F-S cells or TtT/GF cells, though the very slow turnover of endocrine cells may make this a rather rare event in the adenohypophysis. However, it is reported that Anx A1 is a pro-engulfment ligand which, colocalized with phosphatidylserine in the outer membrane leaflet, is required for the efficient clearance of apoptotic cells [114]. FS cells also respond to a number of cytokines (Tables $\mathbf{3}, \mathbf{4}$ ).

\section{COMMUNICATION WITH PITUITARY VASCULA- TURE}

In any tissue, increased cellular activity is usually accompanied by increased blood flow. The blood supply to the anterior pituitary is unusual in that it comes almost exclusively from hypothalamo-pituitary portal veins originating from the capillary plexus in the median eminence and descending the pituitary stalk, so one might expect the oxygen tension in the tissue to be low. Also, flow is likely to be slow both because the input is from the portal veins and also because of the very large vascular sinusoids between the clusters of cells. However, Lafont et al. [130] report a pituitary oxygen tension of $\sim 34 \mathrm{mmHg}$ in anaesthetized rats breathing air.

The principal way in which F-S cells communicate with the vasculature is via the secretion of VEGF $[40,51,126]$ which stimulates the endothelium. F-S cells can also produce nitric oxide [26, 57], and this is stimulated by interferon- $\gamma$ $[57,129]$ and by ATP [26], though whether this can cause vasodilation in the pituitary is unclear. However, F-S cells also produce LIF, which inhibits the proliferation of endothelial cells in the aorta at least [119]. Whether it has a similar effect on pituitary vasculature, how its secretion is regulated and coordinated with that of VEGF and nitric oxide remains unknown.

Unlike the very close anatomical relationships between F-S cell processes and the endocrine cells, F-S cells are separated from the vascular endothelial cells by a substantial perivascular space. VEGF secretion from F-S cells is presumably increased by hypoxia, though this does not appear to have been tested. It is known to be increased by PACAP [126], IL-6 [128], and TGFbeta [63] but the functional important of this is unclear. VEGF secretion is 
Table 3. Immune, Pro- and Anti-Inflammatory Markers Expressed by FS Cells

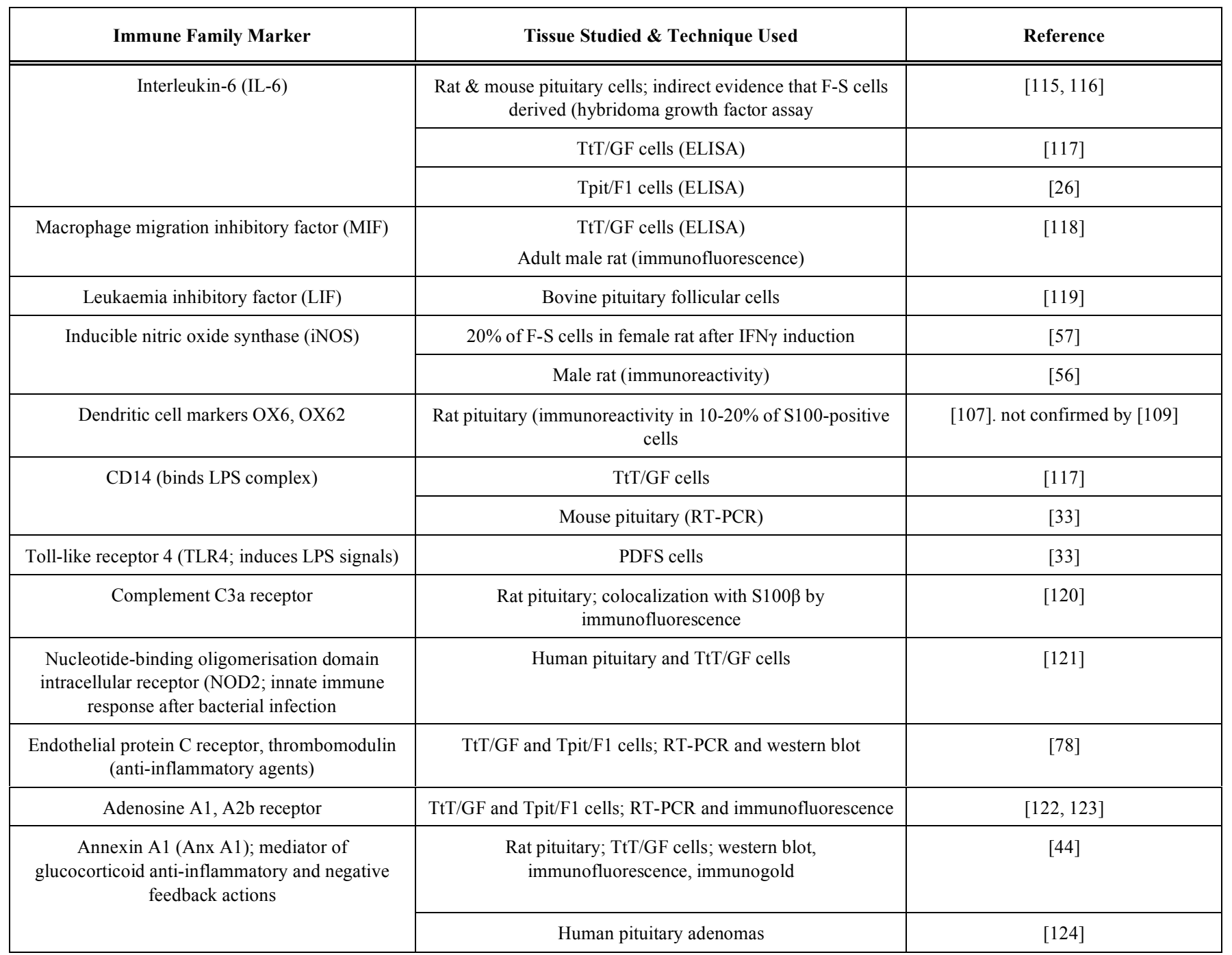

also increased by estradiol which would be consonant with the increased secretory activity at the time of the preovulatory gonadotropin surge, and the lactotroph proliferation during pregnancy. The inhibition of VEGF secretion by glucocorticoids would also be consonant with the inhibition of much pituitary endocrine activity during stress. The observation that the sulphonylurea gliburide markedly enhances VEGF secretion [55] should perhaps sound a note of caution when treatment with sulphonylureas is considered in patients with a known pituitary tumour, as the activity of such tumours is correlated with their vascularity [131] and F-S cells are often observed clustered around pituitary adenomas.

\section{STEM CELLS IN THE ANTERIOR PITUITARY}

The identity of stem cells in the pituitary and the possible involvement of F-S cells or a subset of F-S cells has long been an object of discussion and dispute [132-134]. The turnover of cells in the anterior pituitary is very slow $(\sim 0.05 \%$; [135]). And there have been repeated suggestions that F-S cells, or a subset of those cells (see above) might be involved. Inoue et al. [27, 136] suggest that F-S cells might have stem cells properties because of the ability of the Tpit/F1 cell line to transform into other tissues [137] and this suggestion was supported by Horvath and Kovacs [138] on the basis of structural observations on normal and adenomatous pituitaries. More recently specific markers have been used in the search for pituitary stem cells. Nestin immunoreactivity [139] has identified a population of nonendocrine cells that are also not typical F-S cells; the stem cell antigen Scal likewise identifies a small proportion ('side population') of cells some of which express the F-S cell marker S-100 [132]. SOX-2 has been used to identify a population of adult pituitary cells that form spheres which can differentiate into all pituitary cells types including F-S cells. A small proportion of these cells co-express S-100 and SOX2 [140]. A molecular approach, using nestin coupled to green fluorescent protein, has identified a population of cells surrounding the pituitary cleft (where, incidentally, Anx A1 is also expressed [44]) which also generate subsets of all the pituitary cell types and apparently provide the majority of cells in the adult organ [141]. 
Table 4. Summary of FS Cell Responses to Immune and Inflammatory Mediators

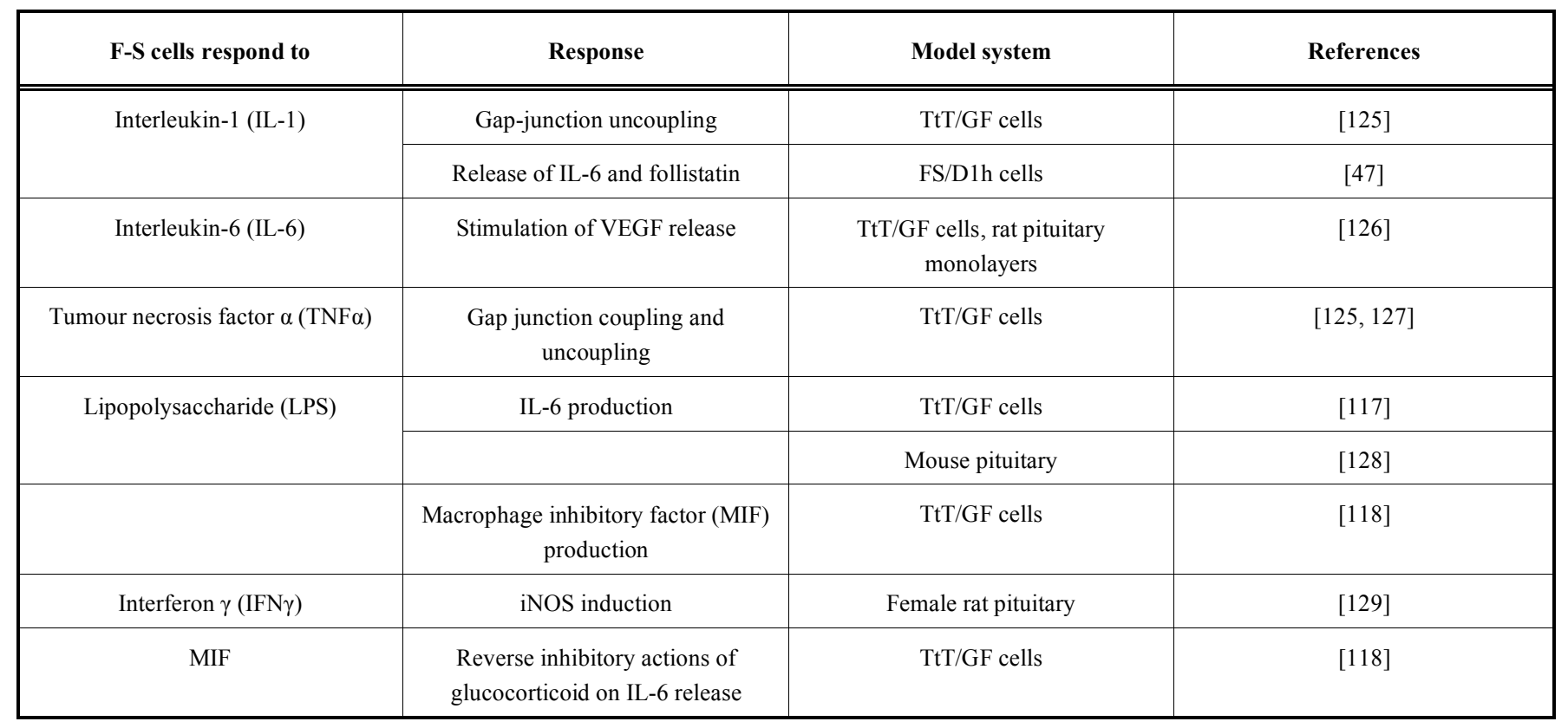

\section{CONCLUSIONS}

The research analysed for this review makes it clear that the group of cells classed as F-S cells, so long the rather ignored 'poor relation' in the anterior pituitary in comparison with the classical endocrine cells, nevertheless have many potentially important functional properties. Furthermore, it seems very likely that, at any one time, there are many subtypes, each with different properties in terms of the signals produced and receptors expressed. The extent to which these subtypes are fixed or plastic is completely unknown, but given the range of signals to which the cells respond and the range of responses it would seem very likely that these are functionally very plastic cells, responding with exquisite precision to the varying physiological conditions. What is clear is that F-S cells form a communication system within the anterior pituitary, interacting with each other and with the surrounding endocrine cells and the vasculature, and using the release of intracellular calcium as an intracellular messenger. Yet even here, although there is now evidence that various signals can alter the expression of gap junction proteins and the intracellular signalling pathways within the cells, we have only a very hazy and limited understanding of how the communication systems within the cells are controlled. Finally, it seems increasingly clear that cells with at least some of the characteristics that have been used to class them as ' $\mathrm{F}-\mathrm{S}$ ' have a stem-cell role in the pituitary. Undoubtedly these 'Cinderella' cells have a lot of secrets that we have yet to uncover.

\section{ABBREVIATION}

$\begin{array}{ll}\text { Anx A1 } & =\text { Annexin } 1 \\ \text { ABC-A1 } & =\mathrm{ABC} \text { transporter } \\ \text { F-S } & =\text { Folliculo-stellate }\end{array}$

\section{REFERENCES}

[1] Fauquier T, Lacampagne A, Travo P, Bauer K, Mollard P. Hidden face of the anterior pituitary. Trends Endocrinol Metab 2002; 13: 304-9.

[2] Denef C. Paracrinicity: 30 years of pituitary crosstalk. J Neuroendocrinol 2008; 20: 1-70.

[3] Fauquier T, Guérineau NC, McKinney RA, Bauer K, Mollard P. Folliculostellate cell network: a route for long-distance communication in the anterior pituitary. Proc Natl Acad Sci USA 2001; 98: 8891-6.

[4] Rinehart JF, Farquhar MG. Electron microscopic studies of the anterior pituitary gland. J Histochem Cytochem 1952; 93: 93-113.

[5] Heinzlmann A, Köves K. The characteristic change in the distribution of S-100 immunoreactive folliculostellate cells in rat anterior pituitary upon long-term estrogen treatment is prevented by concomitant progesterone treatment. Endocrine 2008; 33: 342-8.

[6] Nakajima T, Yamaguchi H, Takahashi K. S100 protein in folliculostellate cells of the rat pituitary anterior lobe. Brain Res 1980; 191: 523-31.

[7] Allaerts A, Jeucken PHM, Debetes R, Hoefakker S, Claassen S, Drexhage HA. Heterogeneity of pituitary folliculostellate cells: implications for interleukin-6 production and accessory function in vitro. J Neuroendocrinol 1997; 9: 43-53.

[8] Yamashita M, Qian ZR, Sano T, Horvath E, Kovacs K Immunohistochemical study on so-called follicular cells and folliculostellate cells in the human adenohypophysis. Pathol Int 2005; 55: 244-7.

[9] Lloyd RV, Jin L, Ruebel KH, Bayliss JM. Analysis of folliculostellate cells by laser capture microdissection and reverse transcription-polymerase chain reaction (LCM-RT/PCR). Methods Enzymol 2002;356: 248-55.

[10] Lloyd RV, Qian X, Jin L, et al. Analysis of pituitary cells by laser capture microdissection. Methods Mol Biol 2005; 293: 233-41.

[11] Soji T, Herbert DC. Intercellular communication between rat anterior pituitary cells. Anat Rec 1989; 224: 523-33.

[12] Sato Y, Hashitani H, Shirasawa N, et al. Intercellular communications within the rat anterior pituitary: XII: Immunohistochemical and physiological evidences for the gap junctional coupling of the F-S cells in the rat anterior pituitary. Tissue Cell 2005; 37: 281-291.

[13] Morand I, Fonlupt P, Guerrier A, et al. Cell-to-cell communication in the anterior pituitary: evidence for gap junction-mediated exchanges between endocrine cells and folliculostellate cells. Endocrinology 1996;137: 3356-67. 
[14] Cónsole GM, Jurado SB, Riccillo FL, Gómez Dumm CL. Immunohistochemical and ultrastructural study of pituitary folliculostellate cells during aging in rats. Cells Tissues Organs 2000; 167: 25-32.

[15] Johnson MD, Gray ME, Pepinsky RB, Stahlman MT. Lipocortin-1 immunoreactivity in the human pituitary gland. J Histochem Cytochem 1990; 38: 1841-5.

[16] Shirasawa N, Yamanouchi H. Glucocorticoids induce glutamine synthetase in folliculostellate cells of rat pituitary glands in vivo and in vitro. J Anat 1999; 194: 567-77.

[17] Ferrara N, Fujii DK, Goldsmith PC, Widdicombe JH, Weiner RI. Transport epithelial characteristics of pituitary follicular cells. Am J Physiol 1987; 252: E304-12.

[18] Ozawa H, Miyachi M, Ochiai I, Tsuchiya S, Morris JF, Kawata M. Annexin-1 (lipocortin-1)-immunoreactivity in the foliculo-stellate cells of rat anterior pituitary: the effect of adrenalectomy and corticosterone treatment on its subcellular distribution. J Neuroendocrinol 2002; 14: 621-8.

[19] Chapman L, Nishimura A, Buckingham JC, Morris JF, Christian HC. Externalization of Annexin I from a F-S-like cell line. Endocrinology 2002; 143: 4330-8.

[20] Alkemade A, Fliers F. Novel pathways for thyroid hormone action in pituitary. Eur J Endocrinol 2006; 154: 491-500.

[21] Otto C, Dieck ST, Bauer K. Dipeptide uptake by folliculostellate cells. Am J Physiol 1996; 271: C210-7.

[22] Pow DV. Visualising the activity of the cystine-glutamate antiporter in glial cells using antibodies to aminoadipic acid, a selectively transported substrate. Glia 2001; 34: 27-38.

[23] Bauer K. Carnosine and homocarnosine, the forgotten, enigmatic peptides of the brain. Neurochem Res 2005; 30: 1339-45.

[24] Inoue K, Matsumoto H, Koyama C, Shibata K, Nakazato Y, Ito A. Establishment of a F-S-like cell linen from a murine thyrotropic pituitary tumor. Endocrinology 1992; 131: 3110-6.

[25] Matsumoto H, Ishibashi Y, Ohtaki T, Hasegawa Y, Koyama C, Inoue K. Newly established murine pituitary F-S-like cell line (TtT/GF) secretes potent pituitary glandular cell survival factors, one of which corresponds to metalloproteinase inhibitor. Biochem Biophys Res Commun 1993; 194: 909-15.

[26] Chen L, Maruyama D, Sugiyama M, et al. Cytological characterization of a pituitary folliculostellate-like cell line, Tpit/F1 with special reference to adenosine triphosphate mediated neuronal nitric oxide synthase expression and nitric oxide secretion. Endocrinology 2000; 141: 3603-10.

[27] Inoue K, Couch EF, Takano K, Ogawa S. The structure and function of F-S cells. Arch Histol Cytol 1999; 62: 205-18.

[28] Nakajima Y, Uchiyama M, Shirai Y, Sakuma Y, Kato M. Acetylcholine increases intracellular $\mathrm{Ca} 2+$ in the rat pituitary folliculostellate cells in primary culture. Am J Physiol Endocrinol Metab 2001; 280: E608-15.

[29] Lees D, Morris JF, Greenfield S, Christian H. Both acetylcholine and choline stimulate externalisation of Anx A1 from S100positive F-S cells of the pituitary gland. Endocr Abstr 2010; 21: P264.

[30] Danila DC, Zhang X, Zhou Y, et al. A human pituitary tumorderived folliculostellate cell line. J Clin Endocrinol Metab 2000; 85: 1180-7.

[31] Pardo FS, Leon S, Carroll R, Black P, Atkins L. Pituitary tumorigenesis and hPit-1 cells. Cancer Genet Cytogenet 2001; 128: 148-53.

[32] Solito E, Mulla A, Morris JF, Christian HC, Flower RJ, Buckingham JC. Dexamethasone induces rapid serinephosphorylation and membrane translocation of Anx A1 in a human folliculostellate cell line via a novel nongenomic mechanism involving the glucocorticoid receptor, protein kinase C, phosphatidylinositol 3-kinase, and mitogen-activated protein kinase. Endocrinology 2003;144: 1164-74.

[33] Tichomirowa M, Theodoropoulou M, Lohrer P, et al. Bacterial endotoxin (lipopolysaccharide) stimulates interleukin-6 production and inhibits growth of pituitary tumour cells expressing the toll-like receptor 4. J Neuroendocrinol 2005; 17: 152-60.

[34] Bilezikjian LM, Blount AL, Leal AMO, Donaldson CJ, Fischer WH, Vale WW. Autocrine/paracrine regulation of pituitary function by activin, inhibin and follistatin. Mol Cell Endocrinol 2004; 225: 29-36.

[35] Ooi GT, Tawadros N, Escalona RM. Pituitary cell lines and their endocrine applications. Mol Cell Endocrinol 2004; 228: 1-21.
[36] Bauer-Dantoin AC, Weiss J, Jameson JL. Gonadotropin-releasing hormone regulation of pituitary follistatin gene expression during the primary follicle-stimulating hormone surge. Endocrinology 1996; 137: 1634-9.

[37] Marin F, Boya J. Immunocytochemical localization of basic fibroblast growth factor in the human pituitary gland. Neuroendocrinology 1995; 62: 523-9.

[38] Oomizu S, Chaturvedi K, Sarkar DK. Folliculostellate cells determine the susceptibility of lactotropes to estradiol's mitogenic action. Endocrinology 2004;145: 1473-80.

[39] Chaturvedi K, Sarkar DK. Role of protein kinase C-Ras-MAPK p44/42 in ethanol and transforming growth factor-beta3-induced basic fibroblast growth factor release from folliculostellate cells. J Pharmacol Exp Ther 2005; 314: 1346-52.

[40] Ferrara N, Henzel WJ. Pituitary follicular cells secrete a novel heparin-binding growth factor specific for vascular endothelial cells. Biochem Biophys Res Commun 1989; 161: 851-8.

[41] Jin L, Burguera BG, Couce ME, et al. Leptin and leptin receptor expression in normal and neoplastic human pituitary: evidence of a regulatory role for leptin on pituitary cell proliferation. J Clin Endocrinol Metab 1999; 84: 2903-11.

[42] Jin L, Tsumamma I, Ruebel KH, Bayliss JM, Lloyd RV. Analysis of homogenous populations of anterior pituitary folliculostellate cells by laser capture microdissection and reverse transcriptionpolymerase chain reaction. Endocrinology 2001; 142: 1703-9.

[43] Sakuma E, Herbert DC, Soji T. Leptin and ciliary neurotrophic factor enhance the formation of gap junctions between F-S cells in castrated male rats. Arch Histol Cytol 2002; 65: 269-78.

[44] Traverso V, Christian HC, Morris JF and Buckingham JC. Lipocortin 1 (Anx A1): a candidate paracrine agent localized in pituitary F-S cells. Endocrinology 1999; 140: 4311-9.

[45] John C, Cover P, Solito E, et al. Anx A1-dependent actions of glucocorticoids in the anterior pituitary gland: roles of the $\mathrm{N}$ terminal domain and protein kinase C. Endocrinology 2002; 143: 3060-70.

[46] Kaiser UB, Lee BL, Carroll RS, Unabia G, Chin WW, Childs GV. Follistatin gene expression in the pituitary: localization in gonadotropes and folliculostellate cells in diestrous rats. Endocrinology 1992;130: 3048-56.

[47] Bilezikjian LM, Leal AM, Blount AL, Corrigan AZ, Turnbull AV, Vale WW. Rat anterior pituitary folliculostellate cells are targets of interleukin-1beta and a major source of intrapituitary follistatin. Endocrinology 2003; 144: 732-40.

[48] Ferrara N, Schweigerer L, Neufeld, G, Mitchell R, Gospaodarawicz D. Pituitary follicular cells produce basic fibroblast growth factor. Proc Natl Acad Sci USA 1987; 84: 5773-7.

[49] Amano O, Yoshitake Y, Nishikawa K, Iseki S. Immunocytochmical localization of basic fibroblast growth factor in the rat pituitary gland. Arch Histol Cytol 1993; 56: 269-76.

[50] Hentges S, Boyadjieva N, Sarkar DK. Transforming growth factor$\beta 3$ stimulates lacatotrop cell growth by increasing basic fibroblast growth factor from F-S cells. Endocrinology 2000; 141: 859-67.

[51] Ferrara N. Vascular endothelial growth factor: basic science and clinical progress. Endocr Rev 2004; 25: 581-611.

[52] Jabbour HN, Boddy SC, Lincoln GA. Pattern and localisation of expression of vascular endothelial growth factor and its receptor flt1 in the ovine pituitary gland: expression is independent of hypothalamic control. Mol Cell Endocrinol 1997; 134: 91-100.

[53] Vidal S, Kovacs K, Cohen SM, Stefaneanu L, Lloyd RV, Scheithauer BW. Localization of VEGF in nontumorous human pituitaries. Endocr Pathol 1999; 10: 109-22.

[54] Leung DW, Cachianes G, Kuang WJ, Goeddel DV, Ferrara N. Vascular endothelial growth factor is a secreted angiogenic mitogen. Science 1989; 246: 1306-9.

[55] Morris JF, Budzik JM, Omer S, Christian H. KATP channels are expressed by pituitary folliculostellate cells and are involved in VEGF secretion. Front Neuroendocrinol 2006; 27: 149-50.

[56] Wang H, Christian HC, Morris JF. Dissociation of nitric oxide synthase immunoreactivity and NADPH-diaphorase enzyme activity in rat pituitary. J Endocrinol 1997; 154: R7-R11.

[57] Vankelecom H, Matthys $P$, Denef $C$. Inducible nitric oxide synthase in the anterior pituitary gland: induction by interferongamma in a subpopulation of folliculostellate cells and in an unidentifiable population of non-hormone-secreting cells. J Histochem Cytochem 1997; 45: 847-57. 
[58] Vlotides G, Zitzmann K, Hengge S, Engelhardt D, Stalla GK, Auernhammer CJ. Expression of novel neurotrophin-1/B-cell stimulating factor-3 (NNT-1/BSF-3) in murine pituitary folliculostellate TtT/GF cells: pituitary adenylate cyclase-activating polypeptide and vasoactive intestinal peptide-induced stimulation of NNT-1/BSF-3 is mediated by protein kinase A, protein kinase C, and extracellular-signal-regulated kinase $1 / 2$ pathways. Endocrinology 2004; 145: 716-27.

[59] Taylor AD, Cowell A-M, Flower J, Buckingham JC. Dexamethasone suppresses the release of prolactin from the rat anterior pituitary gland by lipocortin 1 dependent and independent mechanisms. Neuroendocrinology 1995; 62: 530-42.

[60] Davies E, Omer S, Morris JF, Christian HC. The influence of 17beta-estradiol on Anx A1 expression in the anterior pituitary of the female rat and in a F-S cell line. J Endocrinol 2007; 192: 42942.

[61] Chaturvedi K, Sarkar DK. Involvement of protein kinase Cdependent mitogen-activated protein kinase p44/42 signalling pathway for cross-talk between estradiol and transforming growth factor-beta3 in increasing basic fibroblast growth factor in folliculostellate cells. Endocrinology 2004; 145: 706-15.

[62] Vlotides G, Chen YH, Eigler T, Ren SG, Melmed S. Fibroblast growth factor-2 autofeedback regulation in pituitary folliculostellate TtT/GF cells. Endocrinology 2009; 150: 3252-8.

[63] Renner U, Lohrer P, Schaaf L, et al. Transforming growth factorbeta stimulates vascular endothelial growth factor production by folliculostellate pituitary cells. Endocrinology 2002; 143: 3759-65.

[64] Baratta M, Salieri R, Mainardi GL, Valle D, Giustina A, Tamanini C. Leptin regulation GH gene expression and secretion and nitric oxide production in pit pituitary cells. Endocrinology 2002; 143: 551-5

[65] Duvilanski BH, Zambruno C, Seilicovich A, et al. Role of nitric oxide in control of prolactin release by the adenohypophysis. Proc Natl Acad Sci USA 1995; 92: 170-4.

[66] González-Hernández T, González MC. Gender differences and the effect of different endocrine situations on the NOS expression pattern in the anterior pituitary gland. J Histochem Cytochem 2000; 48: $1639-48$.

[67] Aggarwal S, Gupta S. A possible role for multidrug-resistanceassociated protein in the secretion of basic fibroblast growth factor by osteogenic sarcoma cell line (MG-63). Int J Oncol 1998; 13: 1331-4.

[68] Wein S, Fauroux M, Laffitte J, de Nadaï P, Guaïni C, Pons F, Coméra C. Mediation of annexin-1 secretion by a probenecidsensitive ABC-A1 in rat inflamed mucosa. Biochem Pharmacol 2004; 67: 1195-202.

[69] Chapman LP, Epton MJ, Buckingham JC, Morris JF, Christian HC. Evidence for a role of the adenosine 5'-triphosphate-binding cassette transporter A1 in the externalisation of annexin I from pituitary F-S cells. Endocrinology 2003; 144: 1062-73.

[70] Omer S, Meredith D, Morris JF, Christian HC. Evidence for the role of ABCA1 in the externalisation of Anx A1 from pituitary F-S cells and ABCA1-transfected cell models. Endocrinology 2006; 147: 3219-3227.

[71] Vertongen P, Velkeniers B, Hooghe-Peters E, Robberecht P. Differential alternative splicing of PACAP receptor in pituitary cell subpopulations. Mol Cell Endocrinol 1995; 113: 131-5.

[72] Sudo T, Sakuma Y, Kato M. Bradykinin and angiotensin II-induced $\left[\mathrm{Ca}^{2+}\right]_{\mathrm{i}}$ rise in cultured rat pituitary F-S cells. J Neuroendocrinol 2001; 13: 942-50.

[73] Ozawa H, Ito T, Ochiai I, Kawata M. Cellular localization and distribution of glucocorticoid receptor immunoreactivity and the expression of glucocorticoid receptor messenger RNA in rat pituitary gland. A combined double immunohistochemistry study and in situ hybridization histochemical analysis. Cell Tissue Res 1999; 295: 207-14.

[74] Vidal S, Lloyd RV, Moya L, Scheithauer BW, Kovacs K. Expression and distribution of vascular endothelial growth factor receptor Flk-1 in the rat pituitary. J Histochem Cytochem 2002; 50: 533-40.

[75] Perez Castro C, Nagashima AC, Pereda MP, et al. The gp130 cytokines interleukin-11 and ciliary neurotropic factor regulate through specific receptors the function and growth of lactosomatotropic and folliculostellate pituitary cell lines. Endocrinology 2000;141: 1746-53.
[76] Kabir N, Chaturvedi K, Liu LS, Sarkar DK. Transforming growth factor-beta3 increases gap-junctional communication among folliculostellate cells to release basic fibroblast growth factor. Endocrinology 2005;146: 4054-60.

[77] Kowarik M, Onofri C, Colaco T, Stalla GK, Renner U. Plateletderived growth factor (PDGF) and PDGF receptor expression and function in folliculostellate pituitary cells. Exp Clin Endocrinol Diabetes 2010; 118: 113-20.

[78] Rees DA, Giles P, Lewis MD, Ham J. Adenosine regulates thrombomodulin and endothelial protein $\mathrm{C}$ receptor expression in folliculostellate cells of the pituitary gland. Purinergic Signal 2010; 6: 19-29.

[79] Uchiyama M, Nakajima Y, Sakuma Y, Kato M. Purinergic regulation of intracellular $\mathrm{Ca}^{2+}$ concentration of rat pituitary F-S cells in primary culture. J Neuroendocrinol 2001; 13: 378-85.

[80] Theodoropoulou M, Arzberger T, Gruebler Y, et al. Thyrotrophin receptor protein expression in normal and adenomatous human pituitary. J Endocrinol 2000; 167: 7-13.

[81] Kunzelmann P, Creff A, Bauer K, Mollard P. PACAP and VIP induce changes in cytosolic calcium in putative folliculostellate cells of the mouse pituitary. Ann N Y Acad Sci 2000; 921: 410-4.

[82] Vaudry D, Gonzalez BJ, Basille M, Yon L, Fournier A, Vaudry H. Pituitary adenylate cyclase-activating polypeptide and its receptors: from structure to functions. Pharm Rev 2000; 52: 269-324.

[83] Lohrer P, Gloddek J, Hopfner U, et al. Vascular endothelial growth factor production and regulation in rodent and human pituitary tumor cells in vitro. Neuroendocrinology 2001; 74: 95-105.

[84] Russell JA, Douglas AJ, Brunton PJ. Reduced hypothalamopituitary-adrenal axis stress responses in late pregnancy. Central opioid inhibition and noradrenergic mechanisms. Ann NY Acad Sci 2008; 1148: 428-38.

[85] Burger LL, Haisenleder DR, Aylor KW, Dalkin AC, Prendergast KA, Marshall JC. Regulation of luteinizing hormone- $\beta$ and folliclestimulating hormone (FSH)- $\beta$ gene transcription by androgens: testosterone directly stimulates FSH- $\beta$ transcription independent from its role on follistatin gene expression. Endocrinology 2004; 145: 71-8.

[86] Taylor AD, Cowell AM, Flower J, Buckingham JC. Lipocortin 1 mediates an early inhibitory action of glucocorticoids on the secretion of ACTH by the rat anterior pituitary gland in vitro. Neuroendocrinology 1993; 58: 430-439.

[87] Solito E, Christian HC, Festa M, et al. Post-translational modification plays an essential role in the translocation of annexin A1 from the cytoplasm to the cell surface. FASEB J 2006; 20: 1498-500.

[88] Lewis BM, Pexa A, Francis K, et al. Adenosine stimulates connexin 43 expression and gap junctional communication in pituitary folliculostellate cells. FASEB J 2006; 20: 2585-7.

[89] Ham J, Rees DA. The adenosine a2b receptor: its role in inflammation. Endocr Metab Immune Disord Drug Targets 2008; 8: 244-54.

[90] Alkondon M, Pereira EFR, Cartes WS, Maelicke A, Albuquerque EX. Choline is a selective agonist of $\alpha 7$ nicotinic acetylcholine receptors in rat brain neurons. Eur J Neurosci 1999; 9: 2734-42.

[91] Antoni F. Calcium checks cyclic AMP - corticosteroid feedback in adenohypophysial corticotrophs. J Neuroendocrinol 1996; 8: 65972.

[92] Taylor AD, Christian HC, Morris JF, Flower R, Buckingham J. Evidence from immunoneutralization and antisense studies that the inhibitory actions of glucocorticoids on growth hormone release in vitro require Anx A1 (lipocortin 1). Br J Pharm 2000; 131: 130916.

[93] Taylor AD, Philip JG, John CD, et al. Anx A1 mediates the glucocorticoid inhibition on cyclic adenosine 3',5' monophosphate-stimulated prolactin release. Endocrinology 2000; 141: 2209-19.

[94] Tierney T, Christian H, Solito E, Morris JF, Flower R, Buckingham J. The early-delayed inhibitory action of glucocorticoids on ACTH release is mediated by paracrine-acting Anx A1 from F-S cells: evidence for a co-culture cell line model. J Neuroendocrinol 2003; 15: 1134-43.

[95] Renner U, De Santana EC, Gerez J, et al. Intrapituitary expression and regulation of the gp130 cytokine interleukin- 6 and its implication in pituitary physiology and pathophysiology. Ann N Y Acad Sci 2009; 1153: 89-97. 
[96] Renner U, Gloddek J, Arzt E, Inoue K, Stalla GK. Interleukin-6 is an autocrine growth factor for folliculostellate-like TtT/GF mouse pituitary tumor cells. Exp Clin Endocrinol Diabetes 1997; 105: $345-52$.

[97] Theogaraj E, John CD, Christian HC, Morris JF, Smith SF, Buckingham JC. Perinatal glucocorticoid treatment produces molecular, functional, and morphological changes in the anterior pituitary gland of the adult male rat. Endocrinology 2005; 146 : 4804-13.

[98] Morris JF, Omer S, Davies E, et al. Lack of Anx A1 results in an increase in corticotroph number in male but not female mice. $\mathrm{J}$ Neuroendocrinol 2006; 18: 835-46.

[99] John CD, Christian HC, Morris JF, Flower RJ, Solito E, Buckingham JC. Kinase-dependent regulation of the secretion of thyrotrophin and luteinizing hormone by glucocorticoids and Anx A1 peptides. J Neuroendocrinol 2003; 15: 946-57.

[100] Kawakami S, Fujii Y, Okada Y, Winters SJ. Paracrine regulation of FSH by follistatin in folliculostellate cell-enriched primate pituitary cell cultures. Endocrinology 2002; 143: 2250-8.

[101] Fujii Y, Okada Y, Moore JP Jr, Dalkin AC, Winters SJ. Evidence that PACAP and GnRH down-regulate follicle-stimulating hormone-beta mRNA levels by stimulating follistatin gene expression: effects on folliculostellate cells, gonadotrophs and LbetaT2 gonadotroph cells. Mol Cell Endocrinol 2002;192: 55-64.

[102] Winters SJ, Moore JP. Paracrine control of gonadotrophs. Semin Reprod Med 2007; 25: 379-87.

[103] Winters SJ, Moore JP. Intra-pituitary regulation of gonadotrophs in male rodents and primates. Reproduction 2004; 128: 13-23.

[104] Herkenham M. F-S cells of the anterior pituitary mediate interactions between the endocrine and immune systems. Endocrinology 2005; 146: 33-4.

[105] Allaerts W, Jeucken PHM, Hofland LJ and Drexhage HA. Morphological, immunohistochemical and functional homologies between pituitary folliculostellate cells and lymphoid dendritic cells. Eur J Endocrinol 1991; 125: 92-7.

[106] Hoek A, Allaerts W, Leeneed PJM, Schoemmaker J, Drexhage HA. Dendritic cells and macrophages in the pituitary and the gonads. Evidence for their role in the fine regulation of the reproductive endocrine response. Eur J Endocrinol 1997; 136: 8-24

[107] Allaerts W, Fluitsma DM, Hoefsmit ECM, Jeucken PHM, Morreau $\mathrm{H}$, Bosman FT, Drexhage HA Immunohistochemical, morphological and ultrastructural resemblance between dendritic cells and F-S cells in normal human and rat anterior pituitaries. J Neuroendocrinol 1996; 8: 17-29.

[108] Giometto B, Miotto D, Botteri M, Alessio L, Scanarini M, An SF, Tavolato B. F-S cells of human pituitary adenomas: immunohistochemical study of the monocyte/macrophage phenotype expression. Neuroendocrinology 1997; 65: 47-52.

[109] Sato T, Inoue K. Dendritic cells in the rat pituitary gland evaluated by the use of monoclonal antibodies and electron microscopy. Arch Histol Cytol 2000; 63: 291-303

[110] Allaerts W, Vankelecom H. History and perspectives of pituitary FS cell research Acta Endocrinol (Copenh) 2005; 153: 1-12.

[111] Claudius L, Yoshimi Y, Yoichiro H, Gabriel M, Koichi M. Phagocytotic removal of apoptotic endocrine cells by folliculostellate cells and its functional implications in clusterin accumulation in pituitary colloids in helmeted guinea fowl (Numida meleagris). Acta Histochem 2006; 108: 69-80.

[112] Drewett N, Jacobi JM, Willgoss DA and Lloyd HM. Apoptosis in the anterior pituitary gland of the rat: studies with estrogen and bromocriptine. Neuroendocrinology 1993; 57: 89-95.

[113] Stokreef JC, Reifel CW, and Shin SH. A possible phagocytic role for F-S cells of anterior pituitary following estrogen withdrawal from primed rats. Cell Tissue Res 1986; 243: 255-61.

[114] Arur S, Uche UE, Rezaul K, et al. Annexin I is an endogenous ligand that mediates apoptotic cell engulfment. Develop Cell 2003; 4: 587-98.

[115] Vankelecom H, Carmeliet P, Van Damme J, Billiau A, Denef C. Production of interleukin-6 by F-S cells of the anterior pituitary gland in a histiotypic cell aggregate culture system. Neuroendocrinology 1989; 49: 102-106.

[116] Vankelecom H, Matthys P, Van Damme J, Heremans H, Billiau A, Denef C. Immunocytochemical evidence that S-100-positive cells of the mouse anterior pituitary contain interleukin-6 immunoreactivity. J Histochem Cytochem 1993; 41: 151-6.
[117] Lohrer P, Gloddek J, Nagashima AC, et al. Lipopolysaccharide directly stimulates the intrapituitary interleukin- 6 production by folliculostellate cells via specific receptors and the p38alpha mitogen-activated protein kinase/nuclear factor-kappa B pathway. Endocrinology 2000; 141: 4457-65.

[118] Tierney T, Patel R, Stead CAS, Leng L, Bucala R, Buckingham JC. Macrophage migration inhibitory factor is released from pituitary F-S like cells by endotoxin and dexamethasone and attenuates the steroid-induced inhibition of interleukin 6 release. Endocrinology 2005; 146: 35-43.

[119] Ferrara N, Winer J, Henzel WJ. Pituitary follicular cells secrete an inhibitor of aortic endothelial cell growth: Identification as leukaemia inhibitory factor. Proc Natl Acad Sci USA 1992; 89: 698-702

[120] Francis K, Lewis BM, Akatsu H, et al. Complement C3a receptors in the pituitary gland: a novel pathway by which an innate immune molecule releases hormones involved in the control of inflammation. FASEB J 2003; 17: 2266-8.

[121] Correa-de-Santana E, Fröhlich B, Labeur M, Páez-Pereda M, Theodoropoulou M, Monteserin JL, Renner U, Stalla GK. NOD2 receptors in adenopituitary folliculostellate cells: expression and function. J Endocrinol 2009; 203: 111-22.

[122] Rees DA, Lewis MD, Lewis BM, Smith PJ, Scanlon MF, Ham J. Adenosine-regulated cell proliferation in pituitary folliculostellate and endocrine cells: differential roles for the $\mathrm{A}(1)$ and $\mathrm{A}(2 \mathrm{~B})$ adenosine receptors. Endocrinology 2002; 143: 2427-36.

[123] Rees DA, Lewis BM, Lewis MD, Francis K, Scanlon MF, Ham J. Adenosine-induced IL-6 expression in pituitary folliculostellate cells is mediated via $\mathrm{A} 2 \mathrm{~b}$ adenosine receptors coupled to $\mathrm{PKC}$ and p38 MAPK. Br J Pharmacol 2003; 140: 764-72.

[124] Mulla A, Christian HC, Mendosa N, Morris JF, Solito E, Buckingham JC. Expression, subcellular localisation and phosphorylation status of Anx A1 in human pituitary adenomas and a pituitary carcinoma. Clin Endocrinol 2004; 60: 107-19.

[125] Fortin ME, Pelletier RM, Meilleur MA, Vitale ML. Modulation of GJA1 turnover and intercellular communication by proinflammatory cytokines in the anterior pituitary folliculostellate cell line TtT/GF. Biol Reprod 2006; 74: 2-12.

[126] Gloddek J, Pagotto U, Paez Pereda M, Arzt E, Stalla GK, Renner U. Pituitary adenylate cyclase-activating polypeptide, interleukin-6 and glucocorticoids regulate the release of vascular endothelial growth factor in pituitary folliculostellate cells. J Endocrinol 1999; 160: 483-90.

[127] Meilleur MA, Akpovi CD, Pelletier RM, Vitale ML. Tumor necrosis factor-alpha-induced anterior pituitary folliculostellate $\mathrm{TtT} / \mathrm{GF}$ cell uncoupling is mediated by connexin 43 dephosphorylation. Endocrinology 2007; 148: 5913-24.

[128] Gloddek J, Lohrer P, Stalla J, Arzt E, Stalla GK, Renner U. The intrapituitary stimulatory effect of lipopolysaccharide on ACTH secretion is mediated by paracrine-acting IL-6. Exp Clin Endocrinol Diabetes 2001; 109: 410-5.

[129] Vankelecom H, Matthys P, Denef C. Involvement of nitric oxide in the interferon-gamma-induced inhibition of growth hormone and prolactin secretion in anterior pituitary cell cultures. Mol Cell Endocrinol 1997; 129: 157-67.

[130] Lafont C, Desarménien MG, Cassou M, et al. Cellular in vivo imaging reveals coordinated regulation of pituitary microcirculation and GH cell network function. Proc Natl Acad Sci USA 2010; 9: 4465-70.

[131] McCabe C, Boelaert K, Tannahill LA, et al. Vascular endothelial growth factor, its receptor KDR/Flk-1, and pituitary tumor transforming gene in pituitary tumors. J Clin Endocrinol Metab 2002; 87: 4238-44.

[132] Chen J, Hersmus N, Van Duppen V, Caesens P, Denef C, Vankelecom $H$. The adult pituitary contains a cell population displaying stem/progenitor cell and early embryonic characteristics. Endocrinology 2005; 146: 3985-8.

[133] Vankelecom H. Stem cells in the postnatal pituitary? Neuroendocrinology 2007; 85: 110-30.

[134] Vankelecom H. Non-hormonal cell types in the pituitary candidating for stem cell. Seminars Cell Dev Biol 2007; 18: 559 70 .

[135] Nolan LA, Kavanagh E, Lightman SL, Levy A. Anterior pituitary cell population control: basal cell turnover and the effects of adrenalectomy and dexamethasone treatment. J Neuroendocrinol 1998; 10: 207-15. 
[136] Inoue K, Mogi C, Ogawa S, Tomida M, Miyai S. Are F-S cells in the anterior pituitary gland supportive cells or organ-specific stem cells? Arch Physiol Biochem 2002; 110: 50-3.

[137] Mogi C, Miyai S, Nishimura Y, et al. Differentiation of skeletal muscle from pituitary F-S cells and endocrine progenitor cells. Exp Cell Res 2004; 292: 288-94.

[138] Horvath E, Kovacs K. F-S cells of the human pituitary: a type of adult stem cell? Ultrastruct Pathol 2002; 26: 219-28.
[139] Krylyshkina O, Chen J, Mebis L, Denef C, Vankelecom H. Nestinimmunoreactive cells in rat pituitary are neither hormonal nor typical F-S cells. Endocrinology 2005: 146: 2376-2387.

[140] Fauquier T, Rizzoti K, Dattani M, Lovell-Badge R, Robinson IC. SOX2-expressing progenitor cells generate all of the major cell types in the adult mouse pituitary gland. Proc Natl Acad Sci USA 2008; 105: 2907-12.

[141] Gleiberman AS, Michurina T, Encinas JM, et al. Genetic approaches identify adult pituitary stem cells. Proc Natl Acad Sci USA 2008; 105: 6332-7.

(C) Morris and Christian; Licensee Bentham Open.

This is an open access article licensed under the terms of the Creative Commons Attribution Non-Commercial License (http://creativecommons.org/licenses/by-nc/3.0/) which permits unrestricted, non-commercial use, distribution and reproduction in any medium, provided the work is properly cited. 